\title{
Evaluation of Mixed Corrosion Inhibitors \\ in Cooling Water System
}

Dina Raheem

Collage of Electronic and Electrical Technique

\section{$\underline{\text { Abstract: }}$}

The effect of mixed corrosion inhibitors in cooling system was evaluated by using carbon steel specimens and weight loss analysis. The carbon steel specimens which immersed in mixture of sodium phosphate $\left(\mathrm{Na}_{2} \mathrm{HPO}_{4}\right)$ used as corrosion inhibitor and sodium glocunate $\left(\mathrm{C}_{6} \mathrm{H}_{11} \mathrm{NaO}_{7}\right.$ ) as scale dispersant at different concentrations
$(20,40, \quad 60, \quad 80 \quad \mathrm{ppm})$ and at temperature $25^{\circ} \mathrm{C}$ for (1-5) days. The corrosion inhibitors efficiency was calculated by using uninhibited and inhibited water to give $98.1 \%$. The result of these investigation indicate that the corrosion rate decrease with increase the corrosion inhibitors concentration at $80 \mathrm{ppm}$ and for 5 days, (i.e. corrosion rate $=0.042$ gmd).

Keyword: carbon steel corrosion, corrosion in cooling tower, corrosion inhibitors in cooling tower.

\section{الخلاصة :}

تم تقييم خليط مثبطات التآكل في منظومة التبريد باستعمال معدن كربون ستيل وطريقة فقدان الوزن ـ غمرت نماذج الكربون سنيل في نري خليط من فوسفات الصوديوم كثثبط تأكل وكلو كنيت الصوديوم $\mathrm{C}_{6} \mathrm{H}_{11} \mathrm{NaO} \mathrm{NaO}$ كشتت تكلسات وبتر اكيز مختلفة (20,40,60,80) جزء بالمليون و عند
درجة حر ارة 25مم و لمدة (5-1)أيام ـ تم حساب كفاءة المثبطات باستخدام ماء بدون إضافات ومع الإضافات وكانت كفاءة الخليط 98.1\% عند تركيز80 جزء بالمليون. نتائج البحث تبين أن

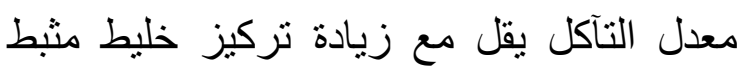
التآكل عند تركيز 80 جزء بالمليون ولمدة 5

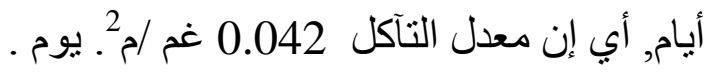




\section{Introduction:}

The term "corrosion" (in a

cooling water system) is defined as the electrochemical deterioration of a metal that is in contact with cooling water. Corrosion occurs when an electric current flows from one part of the metal (anode) through the water (electrolyte) to another part of the metal (cathode). Corrosion takes place at the anode only. The cathode is the driving force of the corrosion action, as shown in the equation;

Metal $\rightarrow$ Metal ions + electrons

$$
\mathrm{M} \rightarrow \mathrm{M}^{\mathrm{n}+}+\mathrm{ne}
$$

This process degrades the metal, reduces its strength, thickness, and in some extreme cases, creates pits and then holes in the material. At some point in the corrosion process, the metal can no longer do its job as a system component. Corrosion, in general, and pitting corrosion, in particular, must be guarded against in order to ensure the long term integrity of the cooling system.[1]
In the corrosion of iron the reaction may proceed by a single step oxidation $\mathrm{Fe}$ into ferric ion:

$\mathrm{Fe} \rightarrow \mathrm{Fe}^{+3}+3 \mathrm{e}^{-}$

In practice, a two-step process occurs in which iron is first oxidized to ferrous ion which depending on the anode potential.

$$
\mathrm{Fe} \rightarrow \mathrm{Fe}^{+2}+2 \mathrm{e}^{-}
$$

And then is oxidized into ferric ion

$$
\mathrm{Fe}^{2+} \rightarrow \mathrm{Fe}^{+3}+\mathrm{e}^{-}
$$

The reactions above take place at the anode and must be balanced by other reduction processes that occur at the cathode. For example:

$\mathrm{O}_{2}(\mathrm{gas})+4 \mathrm{H}+4 \mathrm{e}-\rightarrow 2 \mathrm{H}_{2} \mathrm{O}$

$\mathrm{O}_{2}($ gas $)+\mathrm{H} 2 \mathrm{O}+4 \mathrm{e}-\rightarrow 4 \mathrm{OH}^{-}$

The formation of $\mathrm{OH}$ - at the cathode causes the $\mathrm{pH}$ here to be higher than in the bulk solution. Eventually, ion migration of $\mathrm{OH}-$ occurs, towards the anode, which promotes the formation of ferric hydroxide: 
$\mathrm{Fe}^{+3}+3 \mathrm{OH}^{-} \rightarrow \mathrm{Fe}(\mathrm{OH})_{3}$

Fe $(\mathrm{OH}) 3$ appears in the form of reddish brown colloid. This ferric hydroxide may react further in the presence of ferrous ions to produce $\mathrm{Fe} 3 \mathrm{O} 4 .[2]$

The primary objectives of cooling water treatment are to maintain the operating efficiency of the cooling water system and to protect the equipment that contacts the cooling water. These objectives are accomplished by controlling or minimizing deposition, corrosion, and microbiological growth on the cooling water equipment The deposits that occur in cooling water systems are usually divided into two categories: scale and fouling. The presence of either type of deposit in the heat exchangers or in the film fill can interfere with heat transfer, thereby reducing the efficiency of operation. Deposits can also promote under-deposit corrosion. Scale is formed from minerals, formerly dissolved in water, that were deposited from the water onto heat transfer surfaces or in-flow water lines. As water is evaporated in a cooling tower, the concentration of dissolved solids becomes greater until the solubility of a particular scale-causing mineral salt is exceeded. When this situation occurs in an untreated cooling water system, the scale will form on any surface in contact with the water, especially on heat transfer surfaces. The most common scaling minerals are calcium carbonate $\left(\mathrm{CaCo}_{3}\right)$, calcium phosphate $\left(\mathrm{CaPo}_{4}\right)$, calcium sulfate $\left(\mathrm{CaSo}_{4}\right)$, and silica, usually in that order. Formation of magnesium silicate scale is also possible under certain conditions. Most other salts, including silica, are more soluble in hot water than in cold water; however, most calcium and magnesium salts, including calcium phosphate and calcium carbonate, are more soluble in cold water than in hot water. This is called "reverse solubility." The water temperature will increase as recirculating water passes through the cooling system. As a result, calcium and magnesium scales may form anywhere in the 
system, but most likely on heated surfaces such as heat exchangers or surface condensers. Silica will form in areas having the lowest water temperature, such as in the cooling tower fill.

Scale, in addition to causing physical blockage of piping, equipment, and the cooling tower, also reduces heat transfer and increases the energy use. For example, the thermal conductivity BTU/ [hr (ft2) (F/in)] of copper is 2674 , while the common cooling water scale calcium carbonate has a thermal conductivity of 6.4 BTU/ [hr (ft2) (F/in)].

A calcium carbonate scale of just 1.5 mil thickness is estimated to decrease thermal efficiency by 12.5 $\%$. The principle factors responsible for scale formation are:

1. As alkalinity increases, calcium carbonate- the most common scale constituent in cooling systems - decreases in solubility and deposits.

2. The second-more significantmechanism for scale formation is the in-situ crystallization of sparingly soluble salts as the result of elevated temperatures and/or low flow velocity. Most salts become more soluble as temperature increases, however, some salts, such as calcium carbonate, become less soluble as temperature increases. Therefore they often cause deposits at higher temperatures.

3. High TDS water will have greater potential for scale formation. The common term used to describe the water use efficiency of cooling tower water systems is COC. COC represents the relationship between the makeup water quantity and blow down quantity. COC is a measure of the total amount of minerals that is concentrated in the cooling tower water relative to the amount of minerals in the makeup water or to the volume of each type of water.

The higher the COC, the greater the water use efficiency. Most cooling tower systems operate 
with a $\mathrm{COC}$ of 3 to 10 , where 3 represents acceptable efficiency and 10 represents very good efficiency. It has been found that the range of 5 to $7 \mathrm{COC}$ represents the most cost-effective situation.[3]

The COC of small, medium, and large cooling towers may be controlled by blow down, either automatic or manual, to avoid the high levels of silica and calcium salts that can lead to scale. If the cooling tower is not chemically treated, the COC should be adjusted to be slightly less than the lowest allowable COC value based on all scale-forming water ingredients. The use of chemical treatment permits a higher COC, which is usually limited by either the chemical effectiveness or the water treatment control.[4] water is used in cooling systems as a heat transfer medium and frequently also as the final point to reject heat into the atmosphere by evaporating inside cooling towers. Depending on the quality of available fresh water supply, waterside problems develop in cooling water systems from: Scaling ,- Corrosion ,- Dirt and dust accumulation , - Biological growth .

Any of these problems - or more usually a combination of them result in costly unscheduled downtime, reduced capacity, increased water usage, high operation and maintenance costs, expensive parts replacements, and acid cleaning operations which reduce the life of the cooling system.

Selection of water treatment program for a specific system depends on:

1. System design, including system capacity, cooling tower type, basin depth, materials of construction, flow rates, heat transfer rates, temperature drop and associated accessories

2. Water, including makeup water composition / quality, availability of pre-treatment and assumed cycle of concentration

3. Contaminants, including process leaks and airborne debris 
4. Wastewater discharge restrictions

5. Surrounding environment and air quality

The critical parameters for cooling water are: conductivity, total dissolved solids (TDS), hardness, $\mathrm{pH}$, alkalinity and saturation index. Conductivity is a measure of the ability of water to conduct electrical current and it indicates the amount of the dissolved solids (TDS) in water. Pure distilled water will have a very low conductivity (low minerals) and sea water will have a high conductivity (high minerals). Dissolved solids showed no problem with respect to the cooling capacity of water, since the evaporation rate of seawater, which has 30,000ppm total dissolved solids, is only $1 \%$ less than that of distilled water. The problem with dissolved solids is that many of the chemical compounds and elements in the water will combine to form highly insoluble mineral deposits on the heat transfer surfaces generally referred to as "scale". The scale stubbornly sticks to the surfaces, gradually builds up and begins to interfere with pipe drainage, heat transfer and water pressure.

pH : is a measure of how acidic/basic water is. The range goes from $0-14$, with 7 being neutral. pHs of less than 7 indicate acidity, whereas a $\mathrm{pH}$ of greater than 7 indicates a base. $\mathrm{pH}$ is reported in "logarithmic units," like the Richter scale, which measures earthquakes. Each number represents a 10-fold change in the acidity/baseness of the water. Water with a $\mathrm{pH}$ of 5 is ten times more acidic than water having a $\mathrm{pH}$ of six.

In general, when $\mathrm{pH}$ points to acidic environment, the chances for corrosion increase and when $\mathrm{pH}$ points to alkaline environment, the chances for scale formation increase.

Alkalinity : The $\mathrm{pH}$ values above 7 signify alkalinity. At $\mathrm{pH}$ values less than 8.3 , most of the alkalinity in the 
water is in the bicarbonate form, and scale formation is normally not a problem. However, when the $\mathrm{pH}$ rises above 8.3, the alkalinity converts from the bicarbonate to the carbonate and the scale will start to form.

Hardness :The amount of dissolved calcium and magnesium in water determines its "hardness." The total hardness is then broken down into two categories :a. The carbonate or temporary hardness b. The noncarbonate or permanent hardness Hardness particularly the temporary hardness is the most common and is responsible for the deposition of calcium carbonate scale in pipes and equipment. Technically any bivalent metal ion such as iron, manganese or tin would constitute hardness, but calcium and magnesium are the two most prevalent forms.

Saturation Index :The saturation index of a water or Langlier Saturation Index (LSI) is a measure of the stability of the water with respect to scale formation. When LSI readings are positive they tend to be scale forming, and when they are negative they tend to be corrosive. Normally readings within 1.0 units from zero are considered stable.[5][6]

In cooling water systems, two basic techniques are used to provide corrosion protection to the metals that the water contacts: use of chemical corrosion inhibitors, and raising the $\mathrm{pH}$ of the cooling water.

Most military cooling water systems contain components fabricated primarily of copper alloy and mild steel. Galvanized steel is present in galvanized cooling towers and stainless steel may be present in piping. As the cooling water $\mathrm{pH}$ is increased (ideally to within the range of 8.0 to 9.5 .

Corrosion inhibitors are chemicals, which inhibit or reduce the corrosion rate of the steel or metallic surfaces. Corrosion is an electrochemical phenomenon, which occurs due to anodic and/or cathodic. reactions. Generally, the anodic reaction is the metal ion oxidation, and the cathodic reaction is the hydrogen ion 
reduction. Therefore, the corrosion analysis and the corrosion inhibitors used to control the anodic reactions are classified as anodic corrosion inhibitor and the cathodic reactions are called as cathodic inhibitors.

Anodic Inhibitors form a protective film coating on the anodic metal (where the metal is lost) and thus directly control corrosion by preventing the reaction that results in corrosion. Any unprotected areas will corrode at a much faster rate than the protected areas, a factor that could result in pitting or localized attack of the unprotected areas.

Cathodic Inhibitors form a protective film coating of the cathodic metal (where metal is not lost) and thus indirectly prevent corrosion by interfering with the current flow required for the electrochemical reaction to proceed between the cathodic and anodic metals. The corrosion reaction rate is governed by the size and type of the cathode relative to the anode. Even when cathodic areas are not completely covered by the protective film, corrosion will occur, but usually more slowly and uniformly than when using anodic inhibitors alone. The occurrence of localized corrosion or pitting attack is greatly reduced.

Industrial Cooling water treatment contains these two types of corrosion inhibitors. Anodic inhibitors are called dangerous inhibitors. If inhibitor concentration is low then parts of the anode are not protected. The unprotected anode will experience severe corrosion. corrosion control methodologies are based on the electrochemical principles.[6]

Table (1) shows criteria for the selection of corrosion inhibitors. The principal strategy for a cooling system corrosion protection program is to ensure protection of the metal in the heat exchanger (metal that is the thinnest metal in the system). The secondary goal is to provide protection from corrosion of the mild steel piping. When galvanized steel cooling towers are part of the cooling 
system, specialized corrosion

corroded at $\mathrm{pH}$ levels above 9.0 and inhibitors are the best control below

6.0 . method. Galvanized steel is

Table(1) Criteria for Corrosion Inhibitor Selection

\begin{tabular}{|c|c|c|c|}
\hline Corrosion Inhibitor & $\begin{array}{l}\text { Steel } \\
\text { Aluminum }\end{array}$ & Copper & $\begin{array}{c}\text { pH Range } \\
\text { (ideal) }\end{array}$ \\
\hline \multicolumn{4}{|l|}{ Cathodic Inhibitor } \\
\hline Polyphosphate & $\begin{array}{l}\text { Excellent } \\
\text { Attacks }\end{array}$ & Attacks & $6.5-8.5$ \\
\hline Zinc salts & $\begin{array}{l}\text { Excellent } \\
\text { None }\end{array}$ & None & $6.5-8.5$ \\
\hline Polysilicate & $\begin{array}{l}\text { Excellent } \\
\text { Excellent }\end{array}$ & Excellent & $7.5-10.0$ \\
\hline Molybdate & $\begin{array}{l}\text { Good } \\
\text { Fair }\end{array}$ & Fair & $7.5-10.0$ \\
\hline \multicolumn{4}{|l|}{ Anodic Inhibitor } \\
\hline Orthophosphate & $\begin{array}{l}\text { Good } \\
\text { Attacks }\end{array}$ & Attacks & $6.5-8.5$ \\
\hline Orthosilicate & $\begin{array}{l}\text { Good } \\
\text { Good }\end{array}$ & Good & $7.5-10.0$ \\
\hline
\end{tabular}

Effective corrosion control requires maintaining appropriate $\mathrm{pH}$ levels, plus adding maintenance dosages of chemical corrosion inhibitors. Chemical corrosion inhibitors form a protective film or barrier on the cooling system metal surfaces that have been cleaned prior to adding an initial high dosage of inhibitor. The initial high dosage of inhibitor passivates (protects) the metal. The appropriate dosage of corrosion inhibitor must be maintained continuously in the cooling water to ensure continuing protection. Table (2) shows examples of various passivation and maintenance dosage levels of corrosion inhibitors.[7,8] 
Table (2) Guidelines for passivation film formation and subsequent maintenance

\begin{tabular}{|c|c|c|c|}
\hline \multirow[t]{2}{*}{ Corrosion inhibitor } & \multicolumn{2}{|c|}{ Dosage (ppm) } & \multirow{2}{*}{$\begin{array}{c}\text { Film formation } \\
\text { Time (days) }\end{array}$} \\
\hline & Initial & Maintenance & \\
\hline \multicolumn{4}{|l|}{ Cathodic inhibitor } \\
\hline Polyphosphate & $40-60$ as $\mathrm{po}_{4}$ & $10-20$ as po $_{4}$ & $5-6$ \\
\hline Zinc salts & $10-20$ as zn & $3-5$ as zn & $5-6$ \\
\hline Polysilicate & $40-60$ as $\mathrm{SiO}_{2}$ & $10-20$ as $\mathrm{SiO}_{2}$ & $10-12$ \\
\hline Molybdate & $40-60$ as Mo & $5-20$ as Mo & $10-12$ \\
\hline \multicolumn{4}{|l|}{ Anodic inhibitor } \\
\hline Orthoophosohate & $40-60$ as $\mathrm{po}_{4}$ & $15-20$ as $\mathrm{po}_{4}$ & $5-6$ \\
\hline Orthosilicate & $40-60$ as $\mathrm{SiO}_{2}$ & $10-15$ as $\mathrm{SiO}_{2}$ & $10-12$ \\
\hline \multicolumn{4}{|l|}{ Copper Corrosion inhibitor } \\
\hline Tolyltrizole & $10-20$ as TTA & $1-2$ as TTA & $5-6$ \\
\hline
\end{tabular}

In order to prevent corrosion on galvanized steel cooling towers and associated pipes, formation of a nonporous surface layer of zinc carbonate is one of the effective methods. The formation of zinc carbonate layer is called passivation, which is accomplished by controlling $\mathrm{pH}$ during initial operation of the cooling tower. Control of the cooling water $\mathrm{pH}$ in the range of 7 to 8 for 45 to 60 days usually allows passivation of galvanized surfaces to occur.

In addition to $\mathrm{pH}$ control, operation and moderate hardness levels of 100 to $300 \mathrm{ppm}$ as $\mathrm{CaCO}_{3}$ and alkalinity levels of 100 to $300 \mathrm{ppm}$ as $\mathrm{CaCO}_{3}$ will promote passivation. The chemical cleaning and passivation formulation Applying when the water system $\mathrm{pH}$ is 7.5 to 8.5 ; adjust $\mathrm{pH}$ as required. Formulation 
limitations may require adding separate components to keep things in solution. Other formulations may be used:

*Orthophosphate or hexametaphosphate as $\left(\mathrm{PO}_{4}\right): 60 \mathrm{ppm}$

* Polyacrylate(active) : 20 ppm

* Tolyltrizol (active) : $10 \mathrm{ppm}$

* Soduim gluconate : $50 \mathrm{ppm}$

* Pluronic L-61 (active)(non ionic surfactant with antifoam: 400 ppm

* Phosphate scale inhibitor: 50 ppm

The chemical significations for corrosion inhibitors may be written as following:

1. Polymers (Polyacrylate, etc)_Disperse sludge and distort crystal structure of calcium deposits. Prevent fouling due to corrosion products. Commonly used, cost effective for calcium scale at 5 to $15 \mathrm{mg} / \mathrm{l}$.

2. Phosphonates_- Phosphonates are excellent calcium scale inhibitors at levels from 2 to $20 \mathrm{mg} / \mathrm{l}$.
3. Sodium Phosphates $\left(\mathrm{NaH}_{2} \mathrm{PO}_{4}\right.$, $\left.\mathrm{Na}_{2} \mathrm{HPO}_{4}, \quad \mathrm{Na}_{3} \mathrm{PO}_{4}, \quad \mathrm{NaPO}_{3}\right)_{-}-$ Precipitates calcium as hydroxyapatite $\left(\mathrm{Ca}_{10}(\mathrm{OH})_{2}\left(\mathrm{PO}_{4}\right)_{6}\right)$. Stream $\mathrm{pH}$ must be kept high for this reaction to occur.

4. Sodium Aluminates (NaAl2O4)_Precipitates calcium and magnesium.

5. Coploymers_- These products commonly incorporate two active groups, such as a sulfonate and acrylate, to provide superior performance to a single group compound at use levels at 5 to 20 $\mathrm{mg} / \mathrm{l}$, higher cost.

6. Terpolymers - Like the copolymers, only incorporate three active groups to give yet better performance under severe conditions at use levels of 5 to 20 $\mathrm{mg} / \mathrm{l}$, costly.

7. Polyphosphates - Fairly good calcium scale control under mild conditions. Polyphosphates are of some value for scale control but must be applied cautiously, 
because hydrolysis of the polyphosphate results in the formation of orthophosphate ions.

If this process is not properly controlled, calcium phosphate deposits may result.

8. Tannins, starches, glucose, and lignin derivatives - Prevent feed line deposits by coating scale crystals to produce sludge that will not readily adhere to heat exchanger surfaces.[9]

In general, another types of corrosion inhibitors are :

Mixed inhibitor : is composes of two or three types of inhibitors and majority of the proprietary corrosion inhibitor formula falls into this category. Since chemicals with different characteristics supplement their deficiency with each other, efficacy of the mixed inhibitor increases. Hence, dosage concentration can be significantly reduced, thus, lowering the operating cost and environmental impacts caused by chemicals.
Adsorption inhibitor: Protective absorbed film is formed over the entire metal surface if adsorption inhibitor is used. The film helps to protect electrochemical reactions between metal and aqueous ions. Some of the organic compounds are suitable to act as adsorption inhibitors.[10]

\section{Experimental procedure:}

A lab rotary test was used in this investigation, the beaker used filled with corrosion inhibitors and specimen immersing for $(1-5)$ days and the capacity of beaker was $250 \mathrm{ml}$. The carbon steel specimen materials used in this investigation has the chemical composition which done in the Al- doura refinery by spectrumanalyst as shown in Table (3): 
Table(3) The chemical composition for carbon steel

\begin{tabular}{|l|l|l|l|l|l|l|l|l|l|l|l|l|}
\hline Fe & Si & Mn & Cr & Ni & Mo & Cu & Co & Al & C & S & HB & $\begin{array}{c}\text { Total Elements } \\
\%\end{array}$ \\
\hline 74.2 & 2.2 & 9.0 & 2.2 & 2.7 & 3.5 & 1.1 & 2.5 & 1.3 & 1.2 & 0.1 & 300 & 100 \\
\hline
\end{tabular}

The surface of rectangular carbon steel alloy specimens which have dimensions $(10 \times 3 \times 0.2 \mathrm{~cm}),(9 \times 2$ x $0.25 \mathrm{~cm}$ ), were abraded by using emery paper of different grade numbers $(220,320,400,600)$, after abrasion the surfaces were cleaned with running tap water, followed by acetone rinse for 5 minutes and were dried in discator.

Different concentration of corrosion inhibitor were prepared, $(20,40,60$ and $80 \mathrm{ppm}$ ) mixture of $\mathrm{Na}_{2} \mathrm{HPO}_{4}$ and $\mathrm{C}_{6} \mathrm{H}_{11} \mathrm{NaO}_{7}$.

After specimen's preparations, weighing the specimen and record $\mathrm{W}_{1}$, the specimen was clamped and immersed in mixture of corrosion inhibitors at $20 \mathrm{ppm}$ concentration ,after 1day the immersion specimen, were removed and cleaned by washing with running tap water and brushing them with bristle brush . Then the specimens were immersed in benzene for 5 minutes to ensure removal of corrosion products from metal surface. The specimens were immersed in ethanol were dried in discator, then weights represented as $\mathrm{W}_{2}$. Repeat the procedure by using (40, 60 and $80 \mathrm{ppm}$ ) concentration and immersion for 2,3 and 5 days as shown in fig.(2) . 


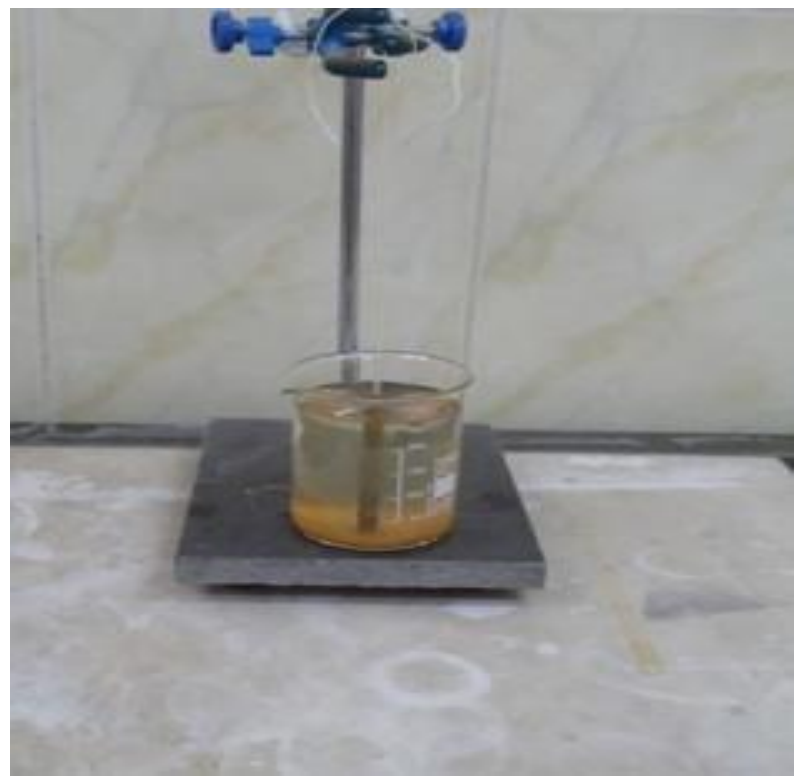

Fig. (1) Carbon steel specimen immersed in mixture of sodium phosphate and sodium gluconate

The efficiency of mixture corrosion inhibitors and scales dispersant (sodium phosphate and sodium glocunate) were calculated ,by using make up water(raw water)without corrosion inhibitor which has the chemical analysis in the table (3) then calculated the corrosion rate for $(1,2,3$ and 5) days as shown in fig. (2), and analyze inhibited water chemically as shown in table (4).

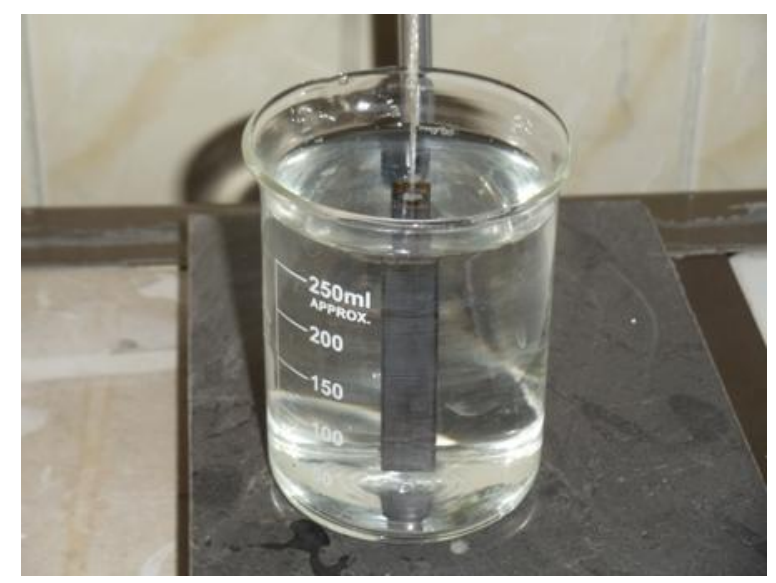

Fig. (2) Carbon steel specimen immersed in makeup water 


\section{$\underline{\text { Results and discussion : }}$}

1. Sodium phosphate effect: The effect of corrosion inhibitor of sodium phosphate indicates that the film of iron phosphate $\left(\mathrm{Fe}_{3}\left(\mathrm{Po}_{4}\right)_{2}\right)$ produced to protect the surface of the specimen to passivate them and prevent the corrosion as shown in the eq.

$$
\begin{aligned}
& 2 \mathrm{Na}_{2} \mathrm{HPO}_{4}+3 \mathrm{Fe}+2 \mathrm{H}_{2} \mathrm{O} \rightarrow\left(\mathrm{Fe}_{3}\right. \\
& \left.\left(\mathrm{Po}_{4}\right)_{2}\right)+4 \mathrm{NaOH}+\mathrm{H}_{2} \quad------(8)
\end{aligned}
$$

The results indicate that when the specimen immersed in the mixture of corrosion inhibitor for 5 days at concentration from 30-40 ppm gave low value of corrosion rate than the immersion for 1 day Which the relation was linear, this mean that the corrosion rate increase with the concentration and the time, as shown in Table (4) and Figure (3).

2. Sodium glocunate effect : The effect of sodium glocunate as scale dispersant indicate that the total dissolved solids (T.D.S.) will be decrease from $3000 \mathrm{ppm}$ to $300 \mathrm{ppm}$ then minimize the electrochemical reaction under the deposit and tubes failed. Because their effect as sequestering agent forming water solution complexes with calcium in alkaline media and with iron in near neutral solutions. As Shown in the equation:

$$
\begin{aligned}
& 2 \mathrm{C}_{6} \mathrm{H}_{11} \mathrm{NaO}_{7}+\mathrm{CaCo}_{3}+\mathrm{H}_{2} \mathrm{O} \rightarrow \\
& \mathrm{Ca}\left(\mathrm{C}_{6} \mathrm{H}_{11} \mathrm{O}_{7}\right)_{2}+\mathrm{NaHCo}_{3}+\mathrm{NaOH}-
\end{aligned}
$$

The concentration at $30-40 \mathrm{ppm}$ of sodium glocunate indicate that the corrosion rate decrease for 5 days of immersion as shown in Table (4) and figure (3) .

3. Time effect : The corrosion rate decrease with increasing time at constant concentration according to the equation of corrosion rate which inversely with time and longer protective layer of mixture will prevent and decrease the corrosion as shown in figure (4). 
Table (4)

Corrosion rate of carbon steel in mixture of sodium phosphate and sodium gluconate at different concentration and $25^{\circ} \mathrm{C}$ temperature

\begin{tabular}{|c|c|c|c|c|c|c|c|}
\hline Test no. & $\begin{array}{l}\text { Time } \\
\text { /day }\end{array}$ & $\begin{array}{c}\text { Conc. in } \\
\text { ppm }\end{array}$ & $\begin{array}{c}\text { Weight/w1 } \\
\text { in gram }\end{array}$ & $\begin{array}{c}\text { Weight/w2 } \\
\text { in gram }\end{array}$ & $\Delta \mathbf{w}$ & $\begin{array}{c}\text { Surface } \\
\text { area } \\
(\mathrm{cm})\end{array}$ & $\begin{array}{c}* \text { C.R. in } \\
\text { gmd }\end{array}$ \\
\hline 1 & 1 & 20 & 47.3300 & 47.3307 & 0.0007 & 0.00415 & 0.16 \\
\hline 2 & 1 & 40 & 47.1400 & 47.1413 & 0.0013 & 0.00652 & 0.19 \\
\hline 3 & 1 & 60 & 47.1500 & 47.1514 & 0.0014 & 0.00652 & 0.21 \\
\hline 4 & 1 & 80 & 47.1500 & 47.1515 & 0.0015 & 0.00652 & 0.23 \\
\hline 5 & 2 & 20 & 47.2999 & 47.3008 & 0.0009 & 0.00415 & 0.10 \\
\hline 6 & 2 & 40 & 47.3300 & 47.3310 & 0.0010 & 0.00415 & 0.12 \\
\hline 7 & 2 & 60 & 47.3300 & 47.3312 & 0.0012 & 0.00415 & 0.14 \\
\hline 8 & 2 & 80 & 47.3300 & 47.3313 & 0.0013 & 0.00415 & 0.15 \\
\hline 9 & 3 & 20 & 47.2990 & 47.3060 & 0.0008 & 0.00415 & 0.064 \\
\hline 10 & 3 & 40 & 47.1400 & 47.1415 & 0.0015 & 0.00652 & 0.076 \\
\hline 11 & 3 & 60 & 47.1400 & 47.1417 & 0.0017 & 0.00652 & 0.087 \\
\hline 12 & 3 & 80 & 47.1400 & 47.1550 & 0.0018 & 0.00652 & 0.092 \\
\hline 13 & 5 & 20 & 47.1436 & 47.1438 & 0.0006 & 0.00652 & 0.018 \\
\hline 14 & 5 & 40 & 47.1434 & 47.1443 & 0.0009 & 0.00652 & 0.027 \\
\hline 15 & 5 & 60 & 47.2990 & 47.2997 & 0.00097 & 0.00415 & 0.033 \\
\hline 16 & 5 & 80 & 47.1423 & 47.1437 & 0.0014 & 0.00652 & 0.042 \\
\hline
\end{tabular}




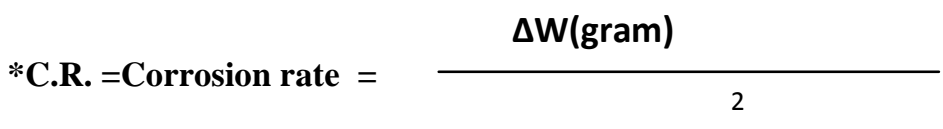

Surface area $(\mathrm{cm}) *$ time (day)

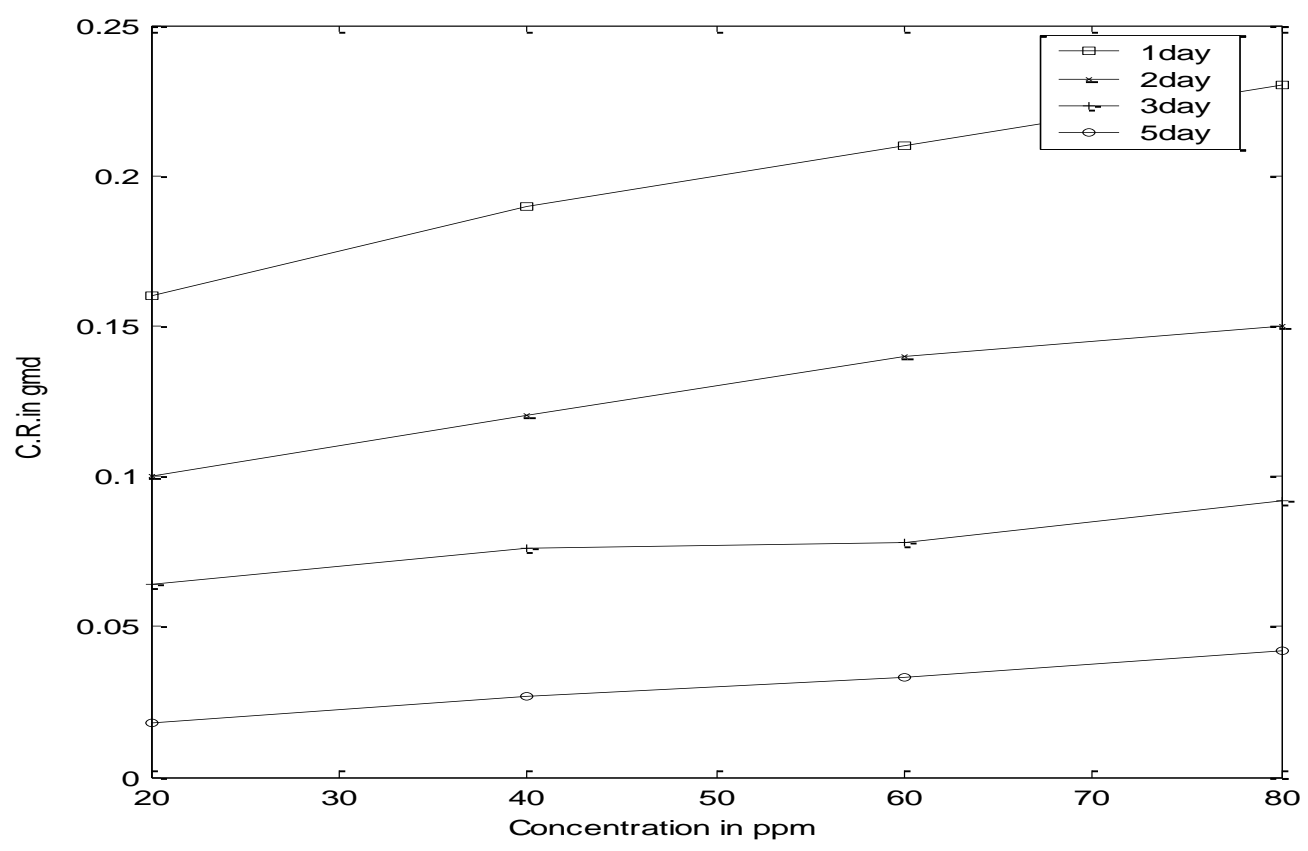

Fig.(3) Corrsion rate and concentration

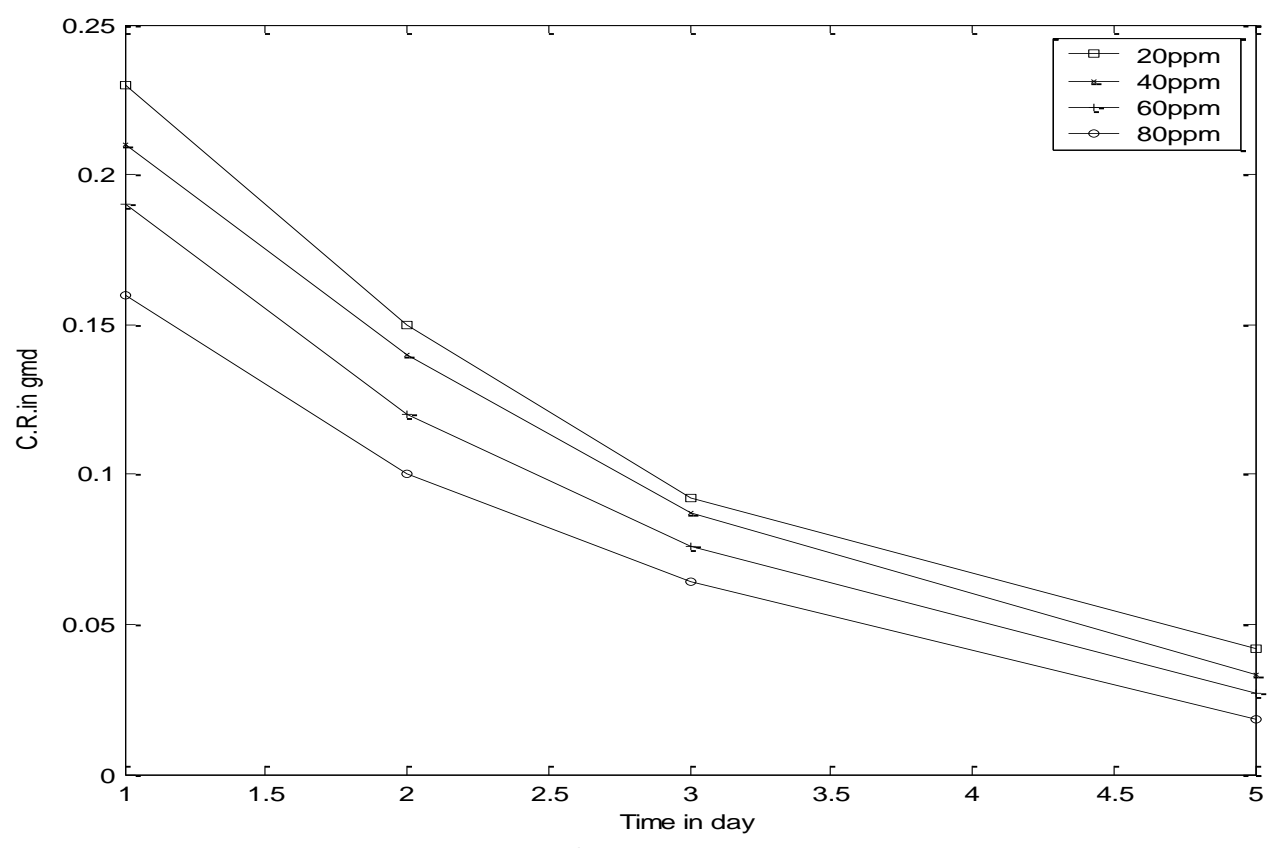

Fig.(4) Corrosion rate and time 
4. Mixture efficiency : The water) were calculated for $1,2,3$ and efficiency of mixture of sodium 5 to compare the efficiency of the phosphate and sodium glocunate mixture by applying the equation of were $(83.3,87.5,93.8$ and $98.1 \%)$ at $80 \mathrm{ppm}$ concentration, The corrosion rate of make up water(raw the efficiency, where the efficiency increasing with time as shown in the table(5) and table (6).

Table (5) The corrosion rate of make up water

\begin{tabular}{|c|c|c|c|c|c|}
\hline Time/day & W1(gram) & W2(gram) & $\Delta \mathbf{w}$ & $\begin{array}{c}\text { Surface area } \\
\text { cm }\end{array}$ & C. R. \\
& & & & & \\
\hline 1 & 47.1423 & 47.1486 & $\mathbf{0 . 0 0 6 3}$ & $\mathbf{0 . 0 0 6 5 2}$ & 0.96 \\
\hline 2 & 47.1414 & 47.1558 & $\mathbf{0 . 0 1 4 4}$ & $\mathbf{0 . 0 0 6 5 2}$ & 1.1 \\
\hline 3 & 47.3200 & 47.3402 & $\mathbf{0 . 0 2 0 2}$ & $\mathbf{0 . 0 0 4 1 5}$ & 1.5 \\
\hline 5 & 47.1435 & 47.2184 & $\mathbf{0 . 0 7 4 9}$ & $\mathbf{0 . 0 0 6 5 2}$ & 2.3 \\
\hline
\end{tabular}

Table (6) The efficiency of mixture of sodium phosphate and sodium glocunate at $80 \mathrm{ppm}$

\begin{tabular}{|c|c|c|c|}
\hline Time (day) & $\begin{array}{c}\text { C.R. } \\
\text { (uninhibited } \\
\text { water) }\end{array}$ & $\begin{array}{c}\text { C.R. } \\
\text { (inhibited } \\
\text { water) }\end{array}$ & $\begin{array}{c}\text { Efficiency } \\
\%\end{array}$ \\
\hline 1 & 0.96 & 0.16 & 83.3 \\
\hline 2 & 1.1 & 0.15 & 87.5 \\
\hline 3 & 1.5 & 0.092 & 93.8 \\
\hline 5 & 2.3 & 0.042 & 98.1 \\
\hline
\end{tabular}




\section{Uninhibited water - inhibited water}

\section{Efficiency $=$}

$* 100 \%$

\section{Uninhibited water}

When carbon steel is immersed in raw water, the anodic reaction is:

$\mathrm{Fe} \rightarrow \mathrm{Fe}^{2+}+2 \mathrm{e}^{-}$

The cathodic reaction is:

$\mathrm{O}_{2}+2 \mathrm{H}_{2} \mathrm{O}+4 \mathrm{e}^{-} \rightarrow 4 \mathrm{OH}^{-}$

,then after 5 days the uniform corrosion will occur while the protective layer of $\mathrm{Fe}_{3}\left(\mathrm{Po}_{4}\right)_{2}$ formed on the surface of carbon steel specimen as shown in figure( 5 ) and figure (6) respectively, the chemical analysis of cooling water (inhibited water) explain this tow statements where the values of alkalinity ,TDS, $\mathrm{TH}, \mathrm{pH}$ and conductivity higher than its values in raw water as shown in table (7).
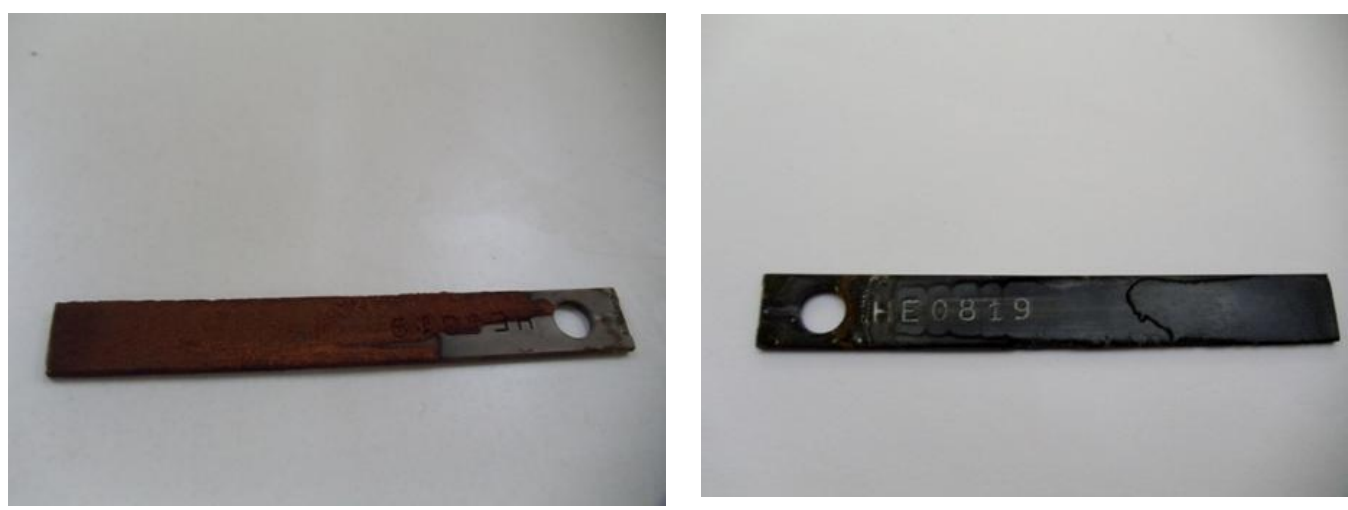

Fig. 5 ) uniform corrosion on carbon steel specimen Fig ( 6 ) protective layer on carbon steel specimen 
Table (7) Chemical analysis for make up(raw water) and cooling tower water

\begin{tabular}{|l|c|c|}
\hline Water Parameter & Make up water & Cooling water \\
\hline Alkalinity as ppm & 144 & 374 \\
\hline Total Hardness as ppm & 250 & 544 \\
\hline T.D.S as ppm & 397 & 1370 \\
\hline pH & 7.4 & $\mathbf{8 . 2 7}$ \\
\hline $\begin{array}{l}\text { Conductivity in } \\
\text { mmhoms }\end{array}$ & 663 & $\mathbf{1 7 1 2}$ \\
\hline $\begin{array}{l}\text { Sodium phosphate as } \\
\text { ppm }\end{array}$ & & $\mathbf{8 0}$ \\
\hline $\begin{array}{l}\text { Sodium gluconate as } \\
\text { ppm }\end{array}$ & & \\
\hline
\end{tabular}

\section{Recommendation}

Some recommendations are suggested to improve the future work : Because of microbiological growth in cooling tower such as algae, fugi and bacteria, then:

1- The treatment with biocides by adding to sample of cooling water :

-Oxidizing Biocides such as (Chlorine,Bromine,Chlorine Dioxide, Ozone, Silver Peroxide, etc)
-Non-oxidizing Biocides :Organic chemical compounds .

- Biodispersants : Surfactant.

2- study the effect of the microbiological growth in cooling tower and measure the corrosion rate of carbon steel with effect of microbiological growth.

3- Calculate the corrosion rate of carbon steel immersed in corrosion inhibitor ,scale dispersant and biodispersant mixing . 


\section{$\underline{\text { References: }}$}

1. P.R. Roberge, "Handbook of Corrosion Engineering", page 13,McGraw- Hill, 1999.

2. R. Wiston, Uhlig's "Corrosion Handbook", 2nd Edition, page 173, John

Wiley and Sons Inc., 2000.

3. File /pdf , "Cooling Tower Technologies and Management - Water Minimization", Australian industry group,2010

4. File / pdf , "power station zero discharge ,cooling tower", 2010.

5. RL Martin, B.A. Alink, T.G. Braga and A.J. McMahon, R. "Weare,Environmentally acceptable water soluble corrosion inhibitors", Corrosion 95, Paper No.36, NACE, 1995.

6. File /pdf, "cooling water problems and solution", 2010.

7. File /pdf ," Inorganic phosphates based corrosion inhibitors for industrial cooling water system, by Dr. E.Moses Road,2010.

8. File://:"Analyst Spring 2003 - Cooling System - Chemical treatment “ by Irvin Cotton.

9. File/pdf, "Industrial water treatment operation and maintenance", by united facilities criteria (UFC), 25 may 2005.

10. C.C.Nathan "Corrosion inhibitors" National Association and Corrosion Engineer, Vol.21,PP.120, No.3, June, (1983). 